\title{
The effect of farmer characteristics on perceptions of the fermented cocoa beans technology in Bengkayang Regency, West Kalimantan
}

\author{
Maswadi *, Shenny Oktoriana, and Anita Suharyani \\ Department of Agribusiness, Faculty of Agriculture, University of Tanjungpura \\ *Email address: maswadi@faperta.untan.ac.id
}

\begin{abstract}
Cocoa Commodities, especially cocoa beans, have a great opportunity to be developed due to high market demand, this must be in line with the good quality of cocoa beans owned with the world market demand standards which means that at the farm level the cocoa farming must implement the Good Agricultural Practices (GAP) and Good Handling Practice (GHP). This study aims to determine the effect of the characteristics of cocoa farmers on farmers' perceptions of fermented cocoa beans. The method used in this study is the survey method. The research location is Sui Duri Village, Sui Raya District, Bengkayang Regency. Data analysis using logit regression. The results showed that the five characteristics of the farmers, namely age, education, land area, number of family dependents and farming experience had a positive influence on farmers' perceptions, this indicates that farmers' characteristics are very important on the farmers' decision to adopt cocoa bean fermentation technology.
\end{abstract}

Keywords: Characteristics of farmers, cocoa, perceptions, Good Agricultural Practices (GAP), Good Handling Practices (GHP)

Citation to this paper should be made as follows :

Maswadi, S. Oktoriana, and A. Suharyani. 2018. The effect of farmer characteristics on perceptions of the fermented cocoa beans technology in Bengkayang Regency, West Kalimantan. Agritropica: Journal of Agricultural Sciences. 1 (2): 85-92. DOI: https:// doi.org/10.31186/J.Agritropica.1.2.85-92

\section{INTRODUCTION}

ASEAN cocoa producing countries are Indonesia, Malaysia, the Philippines, and Thailand, and Indonesia reaches $98 \%$ of the total cocoa-producing plants area in Southeast Asia (source?). So, one of the strategic agricultural products is cocoa (Theobrema cacao L.)

ICCO in the quarterly bulletin of cocoa statistics (2013) states that world cocoa production will decline while world cocoa consumption will increase. This shows that it is estimated that world cocoa demand will increase so that the cocoa commodity has great potential to be developed. According to ICCO (2013), Indonesian cocoa production in 2011 reached 440000 tons. This number places Indonesia as the world's third-largest cocoa producer after Ivory Coast and Ghana. The total world cocoa production in 2011 reached 4
312000 tons with total world cocoa consumption of 3938000 tons (ICCO 2013).

Problems in the downstream subsystem that affect the Indonesian cocoa trade are the low quality of cocoa due to postharvest handling that is not in line yet with GHP (Good Handling Practices) (Bappenas 2011). Approximately $90 \%$ of the cocoa beans sold by farmers are not fermented. In addition, cocoa beans have a high water content, uneven seed size, high seed skin content, high acidity, very diverse and inconsistent flavors. There are cocoa beans attacked by insect pests, attacked by fungi and mixed with dirt or other foreign objects (Ministry of Agriculture 2012).

The low quality of cocoa beans causes Indonesian cocoa beans in export destination countries, especially the United States to be imposed with automatic detention and automatic discount so that the price of cocoa 
beans received and the competitiveness of Indonesian cocoa beans is lower than that produced by the country. other. Domestically, the national cocoa industry lacks raw materials for quality cocoa beans so that the national cocoa industry imports fermented cocoa beans from other producing countries.

Mochtar AH and Darma R (2011) explained that the global cocoa market can generally be divided into two segments based on seed quality, namely the market segment for high-quality cocoa beans characterized by perfectly fermented seeds (categorized as Well Fermented Cocoa Beans or WFCB) and segments the market for cocoa beans with good physical quality but not fermented (categorized as Fair Average Quality or FAQ). The quality standard for the WFCB category is very strict but the world market demand is very large, which is around 2.4 million tons per year or around $80 \%$ of the total world cocoa production. In contrast, the cocoa beans quality standard in the FAQ category is not too strict in regard to seed quality and the world demand for cocoa is relatively small, which is around 600000 tons per year or around 20\% of total world production. Indonesian cocoa that can compete in the WFCB market is only around $2 \%$ of total exports. The main cause is that around $80 \%$ of Indonesia's total cocoa seed production still does not carry out postharvest handling properly, especially the cocoa bean fermentation process has not been carried out.

The cocoa-producing area in West Kalimantan is Bengkayang District, one of the sub-districts that have the National Cocoa Quality and Productivity Improvement Movement (GERNAS) program. GERNAS itself is assisted by Sungai Raya's UPPT (Plant Protection Implementation Unit) to guide farmer groups and farmers who are not included in farmer groups in the cultivation, maintenance, management of pests and diseases and improvement of the quality of cocoa production until the marketing process. Sungai Raya District, Bengkayang Regency is a
District that has the largest area of cocoa plantation, which is equal to 274 ha. Cocoa production in Sungai Raya District, Bengkayang Regency 2016 has decreased to 43 tons compared to 2014, where cocoa production was 45 tons (West Kalimantan Plantation Service, 2016). The problems faced by the Sui Raya District cocoa farmers are the low productivity and quality of cocoa due to cultivation and postharvest methods that have not applied the standards of Good Agricultural Practices (GAP) and Good Handling Practices (GHP).

The success rate of farmers in a farming production process that they manage is inseparable from the farmers' conditions, such as farmer's age, level of education, farming experience, land ownership and cultivated area (internal factors). It is a reflection of the characteristics of farmers and as a benchmark for the attitude of acceptance of various inputs to farming technology. In addition to the internal factors mentioned above, it will also be influenced by the support of external factors such as the availability of technology packages with production facilities in the locality level at the farm level, production credit, production input prices and adequate production output, marketing institutions and extension institutions in working area. Based on the data and information, this study aims to examine the effect of farmer characteristics with perceptions regarding fermentation of cocoa beans by logit regression analysis.

\section{MATERIALS AND METHODS}

The method used is a survey method, namely research conducted by taking a sample of one population and using questionnaires as a basic data collection tool, as well as visiting the research location directly to obtain information needed in research (Nazir, 2005). The location of the study was conducted in Sungai Duri Village, Sui Raya District, 
Bengkayang Regency. Primary data for farmer characteristics were obtained by questionnaire interview method, direct field observation while secondary data was obtained from 2018 village monographs and statistical center bodies to explain the general state of the study area. Materials in the study are:

\section{Characteristics of Farmers}

Farmer characteristics are part of the person and are attached to a farmer himself. These characteristics underlie a person's behavior in other work situations. Farmers' characteristics include age, education, land tenure, number of family members and experience in farming. Characteristics of individuals are part of the person and attached to someone. These characteristics underlie one's behavior in work situations and other situations (Rogers and Shoemaker, 1971 in Damihartini and Jahi, 2005)

\section{Farmer's Perception}

The farmer's perception is the knowledge and behavior of farmers on something, in this case about the technology of fermented cocoa beans. Winardi (2004) perception is a cognitive process, where an individual gives meaning to the environment. Given that each person gives his own meaning to stimuli, it can be said that different individuals, "see" the same thing in different ways.

\section{Data analysis}

Analysis of this data using binary logistic regression (Logit) is part of the regression analysis. According to Firdaus (2011) logistic regression analysis examines the relationship of the effect of explanatory variables $(X)$ on the response variable $(Y)$ through certain mathematical equations. The logistical analysis model involves one response variable $(Y)$ in the form of categorical, influenced by one or more of the explanatory variables $(X)$ that achieve metric or nonmetric combined metrics. Logistic regression analysis is a technique to explain the chance of variable occurrence.

The logit model is a model developed from the LPM (Linear Probability Model) model where $Y$ data consists of 0 and 1 . In the logit model, the data consists of 0 and 1 modified in such a way as to become interval data. This model was originally shaped like the following.

$Y=\alpha+\beta_{1} X_{1}+\beta_{2 X_{2}}+\beta_{3 X_{3}}+\beta_{4 X_{4}}+\beta_{5 X_{5}}+e$

Keterangan :

$\mathrm{Y}=$ Farmer's perception (total score)

$\alpha \quad=$ constant

$\beta_{1}$ s.d $\beta_{5}=$ Regression coefficient to be calculated

$X_{1} \quad=$ Age (th)

$X_{2} \quad=$ Education (th)

$X_{3} \quad=$ Land Area(ha)

$X_{4} \quad=$ Number of family members (org)

$X_{5} \quad=$ Farming experience (th)

$e \quad=$ error

\section{RESULTS AND DISCUSSION}

\section{Coefficient of Determination}

To find out the magnitude of the influence of the five variables on the probability of farmers' perceptions of cocoa bean fermentation technology is indicated by the value $\mathrm{R} 2$ of the logit model regression model.

Table 1. Results of R Square

\begin{tabular}{llll}
\hline \multicolumn{4}{c}{ Model Summary } \\
\hline Step & $\mathbf{- 2} \log$ Likelihood & Cox \& Snell R Square & Nagelkerke R Square \\
\hline 1 & $17.870^{a}$ & .489 & .698 \\
\hline a. & $\begin{array}{l}\text { Estimation terminated at iteration number 7 because parameter estimates changed by less } \\
\text { than, } 001\end{array}$ \\
Source: Primary Data Analysis, 2018 &
\end{tabular}


Cox \& Snell $\mathrm{R}$ square values were obtained at 0.489 . This result means that $48.9 \%$ of the probability of farmers' perceptions of fermented cocoa beans can be influenced by age, education, land area, number of family members and farming experience.

\section{Correlation between Variables (Multicollinearity Test)}

Multicollinearity shows a strong relationship between independent variables. If Multicollinearity occurs, the estimation of the model is not good. Multicollinearity is measured by the correlation between variables. The results of testing the correlation between variables are as follows:
Multicollinearity test results show that all correlation values between independent variables have a correlation value below 0.70 or still low. This means that there is no problem with multicollinearity which also means that the variables are independent of each other.

\section{Logit Model Regression Coefficient Test}

After obtaining a fit logit model regression model that does not require modification of the model, hypothesis testing can be done. The results of hypothesis testing are carried out using a partial test. The partial test of the significance of each variable is done using the Wald test and the following results are obtained:

Table 2. Inter Variable Correlation

\begin{tabular}{llllllll}
\hline \multicolumn{7}{c}{ Correlation Matrix } \\
\hline Step 1 & Constant & X1 & X2 & X3 & X4 & X5 \\
& X1 & 1.000 & -.757 & -.586 & .174 & -.428 & -.571 \\
& X2 & -.627 & 1.000 & .501 & -.226 & .320 & .054 \\
& X3 & -.533 & .475 & 1.000 & -.289 & .425 & -.034 \\
& X4 & -.234 & -.253 & -.231 & 1.000 & -.483 & -.362 \\
& X5 & -.357 & .329 & .517 & -.581 & 1.000 & -.092 \\
& -.415 & .112 & -.123 & -.235 & -.092 & 1.000
\end{tabular}

Source: Primary Data Analysis, 2018

Table 3. Logit Model Regression Test Results

\begin{tabular}{llllllll}
\hline \multicolumn{7}{c}{ Variables in the Equation } \\
\hline Step 1 a $^{\mathrm{a}}$ & X1 & B & S.E. & Wald & df & Sig. & Exp(B) \\
& X2 & .256 & .125 & 3.420 & 1 & .048 & 1.301 \\
& X3 & .412 & .305 & 1.519 & 1 & .035 & 1.598 \\
& X4 & .391 & 2.491 & .023 & 1 & .879 & 1.460 \\
& X5 & .174 & .848 & .074 & 1 & .040 & .865 \\
Constant & .312 & .293 & 1.315 & 1 & .026 & 1.359 \\
& & -19.738 & 10.499 & 4.712 & 1 & .042 & .000
\end{tabular}

Variable (s) entered on step 1: X1: Age, X2: Education, X3: Land Area, X4: Number of Family Members, X5: Meditating Experience

Source: Primary Data Analysis, 2018 
Testing the regression coefficient to test how far all the independent variables included in the variable have an influence on the fixed variable. The way the Wald value is statistics is compared to chi-square tables. While the probability value (sig) is compared with a. Then the decision obtained is Wald count of 4.712> a then Ho is rejected, or the hypothesis which states that the independent variable affects the dependent variable is rejected. Based on the data in table 6, the following equations can be arranged:

\section{Farmer's Perception $=-19,738+0,256 X 1+0$, $412 \times 2+0,391 \times 3+0,174 \times 4+0,312 \times 5+e$}

\section{Effect of Logit Model Regression Analysis}

The influence of each independent variable such as age, education, out of the land, the number of family members and experience of farming on non-independent variables of farmers' perceptions are as follows:

\section{Age $\left(X_{1}\right)$}

The significance of the effect of the age variable on farmer perceptions is based on the Wald value obtained at 3,420 with a significance of 0.035 . Significant values that are below 0.05 indicate a significant effect of age variables on the perceptions of farmers. So the hypothesis which states that age has a significant positive influence on the perceptions of farmers is accepted.

The reality in the field of all respondent farmers is included in the productive age. At productive age allows a person to be able to think well, increase faster and more accurately so competent in responding to problems and making decisions. Someone who has a good perception of something will influence an action in determining a good decision including in applying the technology of fermented cocoa beans. According to Nofri ayinun hiola, indriani (2018) that the age of most farmers is in the productive age at the age of 15-55 years. This means that the physical and energy of the farmers are still productive in managing their farming.

\section{Education $\left(X_{2}\right)$}

Testing the significance of the effect of educational variables on farmer perceptions are based on the Wald value obtained at 1.519. With a significance of 0.035 . Significance values that are below 0.05 indicate a significant effect of education variables on the perceptions of farmers. This is in line with the opinion of Piter Barto Tarukallo, Andi Alimuddin Unde, Ladaha (2014) that education is one of the important factors in supporting the success of the development. The high level of education of the population in an area will affect the quality of human resources which is the subject and object of development in the region, besides that it can also influence the adoption of an innovation because generally, highly educated people will be more open to change. Farmers with higher education are easy to digest new knowledge and technology (Rahmadona, Fariyanti, \& Burhanuddin, 2015) and their ability to receive, filter and implement new innovations is higher (Sasongko, Witjaksono, \& Harsoyo, 2014).

The condition in the field of average farmer education is SMP as much as $56 \%$ so that the mindset, attitudes, and behavior of farmers towards something fermentation technology is still said to be low so that it does not significantly influence farmers' perceptions of the technology of fermented cocoa beans.

\section{Land area $\left(X_{3}\right)$}

Testing the significance of the effect of educational variables on farmer perceptions are based on Wald values obtained at 0.058 with the significance of 0.038 . Significance values that are above 0.05 indicate a significant effect of the variable land area on farmers' perceptions. The situation in the field is that the largest farmer's land area is $53 \%$ with a land area of 1-2 ha and $47 \%$ with land below 1 ha. With the area of land owned by farmers, it 
is expected that it is easy to accept the technology of fermented cocoa beans because it is related to the amount of cocoa harvest.

This research is in line with the results of the study showing that $52 \%$ of farmers have large land (> $2 \mathrm{ha}$ ), so it will be easier and faster to adopt new technology, due to better economic capabilities (Romdon, Supardi, \& Sasongko, 2012). The wider the land used for farming, the more motivated farmers are to adopt new technologies (Rahmawati, Widjayanthi, \& Raharto, 2010). Farmers who have narrow land (as much as $48 \%$ ) tend to maintain the existing cropping pattern. This situation is caused by the thought of large risks and uncertainties in production and marketing that might occur if you choose to adopt new innovations (Theresia, Fariyanti, \& Tinaprilla, 2016).

\section{Number of family members $\left(X_{4}\right)$}

Testing the significance of the effect of educational variables on farmer perceptions are based on Wald values obtained at 0.074 with a significance of 0.040 . Significance values that are below 0.05 indicate a significant effect of the variable number of family members on the perceptions of farmers. This variable has no significant effect because the mindset of the farmer family is more different. The less number of family members, the mindset of the farmer family will be more varied in accepting new innovations or technology. The average cocoa farmer in Sungai Duri Village, Sungai Raya Subdistrict has a family number of 3 people at $56 \%$ so that the mindset of the farm family is varied and the demands of household needs are not that great.

This is supported by Soekartawi (2003), namely the greater the number of family members the greater the demands of household needs. So that it influences farmers' decisions to do many activities/activities that can increase family income. The connection with the perception of fermentation technology is that by applying fermentation technology to cocoa beans it is expected to increase the selling price of cocoa beans which can later increase family income. Family dependence is one of the main reasons for household women to participate in helping husbands to decide to work to earn income. The more respondents have children and dependents, the more time the respondent provides to work (Sihol Situngkir, 2007).

\section{Farming Experience $\left(X_{5}\right)$}

The significance test of the effect of experience variables on farmer perceptions is based on the Wald value obtained at 1.315 with a significance of 0.026 . Significance values that are below 0.05 indicate that there is no significant effect of the farming experience variable on farmers' perceptions.

The experience of farming will help farmers in making decisions that support the success of their farming, because the longer the experience they have, the higher the skills they have. But having a long experience is not enough because skills and abilities are also influenced by the level of education of farmers.

Farmer education is closely related to the ability of farmers to adopt new technologies that can support the optimization of the use of inputs in farming. Higher farmer education makes it easier for farmers to adopt technology obtained from agricultural extension workers who are expected to be able to increase their farming production and eventually increase their farming profits through the sale of crops namely dried cocoa beans. This is in line with Abdul Farid's research, Ugik Romadi, Djoko Witono (2018), that farming experience is dominated by farmers who have more than 10 years of farming experience, namely 71 farmers (89\%). This condition is a natural thing because if we relate it to the age of the farmer where the respondent's farmer with the age of 40 years and over reaches 68 people $(85 \%)$. 


\section{CONCLUSION AND RECOMMENDATION}

The test results of the influence of farmer characteristics on farmers' perceptions of cocoa bean fermentation technology stated that all input variables had a significant effect, namely age, education, land area, family members and farming experience, which meant that characteristics were very important in making decisions and accepting new innovations for developing farming better to improve the economy of farmer families, especially cocoa farmers in the village of Sui Duri, Sui Raya District, Bengkayang Regency, West Kalimantan.

\section{REFERENCES}

[Bappenas] Badan Perencanaan Pembangunan Nasional. 2011. Evaluasi Pelaksanaan Gerakan Nasional Peningkatan Produksi dan Mutu Kakao 2009-2010. Jakarta (ID): Kementrian Perencanaan Pembangunan Nasional.

[ICCO] International Cocoa Organization. 2013. Quarterly Bulletin of Cocoa Statistics, Vol XXXIV, No. 3, Cocoa Year 2009/2010. London(GB): ICCO Annual Report.

Abdul Farid., Ugik Romadi \& Djoko Witono (2014). Faktor - faktor Yang Mempengaruhi Adopsi Petani Dalam Penerapan Ssitem Tanam Jajar Legowo di Desa Sukosari Kecamatan Kasemba Kabupaten Malang Jawa Timur. Jurnal Penyuluhan, Maret 2018 Vol 14 No.1.

Damihartini, R.S; \& Amri Jahi. 2005. Hubungan karakteristik Petani dengan Kompetensi Agribisnis pada Usahatani Sayuran di kabupaten Kediri Jawa Timur. Jurnal Penyuluhan Vol 1 No.1.
Dinas Perkebunan Provinsi Kalimantan Barat. 2016. Data Luas Areal, Produksi dan Produktivitas Perkebunan Kakao Kabupaten Bengkayang. Pontianak.

Firdaus M, Harmini dan Farid. 2011. Aplikasi Metode Kuantitatif untuk Manajemen dan Bisnis. Bogor (ID): IPB Press.

Nazir, M., 2005. Metode Penelitian. Cetakan Keenam. Penerbit Ghalia Indonesia

Nofri Ayinun., Hiola \& Indrian (2015). Tingkat Adopsi Inovasi Sistem Tanam Jajar Legowo pada Tanaman Padi do Desa Ilomangga Kecamatan Fabongo Kabupaten Gorontolo. Jurnal Agropolitan Volume 5 Nomor 1 Bulan Juli 2018.

Rahmadona, L., Fariyanti, A., \& Burhanuddin. (2015). Analisis Pendapatan Usahatani bawang Merah di Kabupaten Majalengka. AGRISE, XV(2), 72-84.

Rahmawati, D. R., Widjayanthi, L., \& Raharto, S. (2010). Tingkat Adopsi Teknologi Program Prima Tani dan Penguatan Kelembagaan dengan PT Tri Sari Usahatani. J-SEP, 4(1), 1-14.

Romdon, A. S., Supardi, S., \& Sasongko, L. A. (2012). Kajian Tingkat Adopsi Teknologi pada Pengelolaan Tanaman Terpadu (PTT) Padi Sawah (Oryza sativa L) Di Kecamatan Boja, Kabupaten Kendal. Jurnal IlmuIlmuPertanian, 8(1), 42-60.

Sasongko, W. A., Witjaksono, R., \& Harsoyo. (2014). Pengaruh Perilaku Komunikasi terhadap Sikap dan Adopsi Teknologi Budidaya Bawang Merah Di Lahan Pasir Pantai Kecamatan Sanden, 
Kabupaten Bantul. Agro Ekonomi, 24(1), 35-43.

Situngkir, Sihol. Lubis Pulina dan Erida. 2007. Peranan Ibu Rumah Tangga Dalam Meningkatkan Pendapatan Keluarga (Kasus: Pedagang Sayur di Kota Madya Jambi). "Jurnal Manajemen dan Pembangunan", Ed. 7, Juli 2007.

Soekartawi, 2003. Agroindustri Dalam Perspektif Sosial Ekonomi. Universitas Indonesia Press. Jakarta
Theresia, V., Fariyanti, A., \& Tinaprilla, N. (2016). Pengambilan Keputusan Petani Terhadap Penggunaan Benih Bawang Merah Lokal dan Impor di Kabupaten Cirebon, Jawa Barat. AGRARIS: Journalof Agribusiness and Rural Development Research, 2(1), 50-60. https://doi.org/10.18196/agr.2125

Winardi, J. 2004. Motivasi dan Pemotivasian dalam Manajemen. Jakarta: Rajawali Pers. 